University of Nebraska - Lincoln

DigitalCommons@University of Nebraska - Lincoln

Faculty Publications from the Harold W. Manter Laboratory of Parasitology

6-1985

\title{
Helminth Parasites of Thomomys bulbivorus (Richardson) (Rodentia: Geomyidae), with the Description of a New Species of Hymenolepis (Cestoda)
}

Scott Lyell Gardner

University of Nebraska - Lincoln, slg@unl.edu

Follow this and additional works at: https://digitalcommons.unl.edu/parasitologyfacpubs

Part of the Parasitology Commons

Gardner, Scott Lyell, "Helminth Parasites of Thomomys bulbivorus (Richardson) (Rodentia: Geomyidae), with the Description of a New Species of Hymenolepis (Cestoda)" (1985). Faculty Publications from the Harold W. Manter Laboratory of Parasitology. 73.

https://digitalcommons.unl.edu/parasitologyfacpubs/73

This Article is brought to you for free and open access by the Parasitology, Harold W. Manter Laboratory of at DigitalCommons@University of Nebraska - Lincoln. It has been accepted for inclusion in Faculty Publications from the Harold W. Manter Laboratory of Parasitology by an authorized administrator of DigitalCommons@University of Nebraska - Lincoln. 


\title{
Helminth parasites of Thomomys bulbivorus (Richardson) (Rodentia: Geomyidae), with the description of a new species of Hymenolepis (Cestoda)
}

\author{
SCOTT LyELL GaRDNER \\ Department of Biology, University of New Mexico, Albuquerque, NM, U.S.A. 87131 \\ Received July 4, 1984
}

GARDNER, S. L. 1985. Helminth parasites of Thomomys bulbivorus (Richardson) (Rodentia: Geomyidae), with the description of a new species of Hymenolepis (Cestoda). Can. J. Zool. 63: 1463-1469.

A cestode, Hymenolepis tualatinensis n. sp., is described from the pocket gopher, Thomomys bulbivorus (Richardson) (Rodentia: Geomyidae), from the Willamette Valley in Oregon. Helminths of four additional species were found. Trichuris fossor Hall, 1916, Ransomus rodentorum Hall, 1916, Heligmosomoides thomomyos Gardner and Jasmer, 1983, and Hymenolepis horrida (von Linstow, 1901), of which all but $H$. thomomyos represent new host records. A significant change in prevalence of the whipworm $T$. fossor in the population of $T$. bulbivorus from spring through summer was noted. Significant differences in prevalence of infection of helminths in pocket gophers collected from two different localities in the Willamette Valley were observed.

GARDNER, S. L. 1985. Helminth parasites of Thomomys bulbivorus (Richardson) (Rodentia: Geomyidae), with the description of a new species of Hymenolepis (Cestoda). Can. J. Zool. 63: 1463-1469.

On trouvera ici la description d'Hymenolepis tualatinensis n. sp., cestode parasite du gaufre Thomomys bulbivorus (Richardson) (Rodentia: Geomyidae), de la vallée de la Willamette en Oregon. Quatre autres espèces d'helminthes ont été trouvées également: Trichuris fossor Hall, 1916, Ransomus rodentorum Hall, 1916, Heligmosomoides thomomyos Gardner and Jasmer, 1983 et Hymenolepis horrida (von Linstow, 1901); toutes ces espèces, sauf $H$. thomomyos sont trouvées pour la première fois chez ce gaufre. La fréquence du nématode $T$. fossor a subi une variation significative chez la population de $T$. bulbivorus du printemps à la fin de l'été. La fréquence des infections par les helminthes différait significativement aussi chez les gaufres de deux sites différents de la vallée.

[Traduit par le journal]

\section{Introduction}

Geomyidae is a nearctic family, with a fossil record extending from the early Miocene (Kurtén and Anderson 1980). All members of the family are fossorial with some genera more highly specialized for fossoriality (Russell 1968). Species of the genus Thomomys are distributed from southwestern and south-central Canada (southern British Columbia, Manitoba, and Saskatchewan) throughout the western part of the United States to southern Mexico (Oaxaca and Veracruz states) (Hall and Kelson 1959).

Little information is available concerning the endoparasites of Thomomys bulbivorus (Richardson), a pocket gopher endemic to the Willamette Valley of Oregon. Heligmosomoides thomomyos Gardner and Jasmer, 1983 (Nematoda: Heligmosomidae) has been the only helminth parasite reported from $T$. bulbivorus up to the present. This nematode was collected from the latter near Corvallis and Gaston, Oregon, as well as from Thomomys bottae Eydoux and Gervais in northern California.

The present report is based on helminths from pocket gophers collected in the Willamette Valley. In addition to faunistic data, description of a species of cestode is provided.

\section{Materials and methods}

Seventy-three pocket gophers, T. bulbivorus, collected between March 1979 and June 1982 from areas near Gaston and Corvallis, Oregon, were examined for helminths.

The Gaston site, near the western margin of the range of T. bulbivorus (cf. Hall and Kelson 1959) was primarily farmland interspersed by strips of riparian forest and grass meadows in old pastures and undisturbed areas. Most of the gophers were collected on the floodplain of the Tualatin river, the soils of which consist of a deep sandy loam. At higher elevations, the soil is a dense sand-clay material with little organic content.

The Corvallis site, an island surrounded by sloughs and water channels of the Willamette river, is approximately in the center of the geographic range of T. bulbivorus (cf. Hall and Kelson 1959). The soil consists of a deep sandy loam deposited by river flooding. Most of the gophers were collected from monoculture alfalfa and clover fields, with a small number obtained along field margins and in other areas with more diversified vegetation. The area is surrounded by strips of riparian forest bordering the waterways. All gophers were collected by trapping or by shooting and were necropsied as soon as possible.

Cestodes were placed in freshwater for a short time to relax and then fixed in hot aqueous 10\% Formalin. They were stained with Ehrlich's acid hematoxylin or Semichon's acetic carmine, dehydrated in ethanol, cleared in xylene or terpineol, and mounted in Canada balsam. Selected specimens were sectioned transversely at $15 \mu \mathrm{m}$ to study the internal organs. Wet mounts of eggs, from either fresh or Formalinpreserved specimens, were prepared and photographed.

Nematodes also were fixed in a $10 \%$ Formalin solution, preserved in $70 \%$ aqueous ethanol and $3 \%$ glycerol, and cleared by evaporation of the ethanol. They were temporarily mounted in glycerol and $2 \%$ lactic acid.

The life cycles of the two species of cestodes recovered during this study were investigated using the following methods. Laboratoryreared specimens of Tribolium castaneum Herbst, $T$. confusum du Val, and Tenebrio molitor Linnaeus were used as experimental intermediate hosts. Beetles of both species of Tribolium were exposed to infection by cestodes following the method of Heyneman (1958). Attempts to infect Tenebrio molitor with cestodes were made following the method of Gardner (1983)

For experimental infection of laboratory mammals, cysticercoids were obtained by feeding eggs of $H$. diminuta (from Carolina Biological Supply Co.) from strobilae that were reared in laboratory rats, Rattus norvegicus Berkenhout, to $T$. molitor. Beetles were dissected and the cysticercoids were removed. Each pocket gopher received a small number of cysticercoids $(<10)$ to reduce the crowding effect on size and development of the strobilae (Roberts 1980). The specimens of $H$. diminuta used for comparisons were obtained experimentally in laboratory rats and from experimentally infected pocket gophers, Thomomys mazama (Merriam) and Pappogeomys castanops (Baird).

Seasonal changes in prevalence of infection of those helminths monitored were tested for statistical significance using an arc sine transformation $t$-statistic (Sokal and Rohlf 1969). Differences in prevalence of helminths between the two study sites were analyzed using 


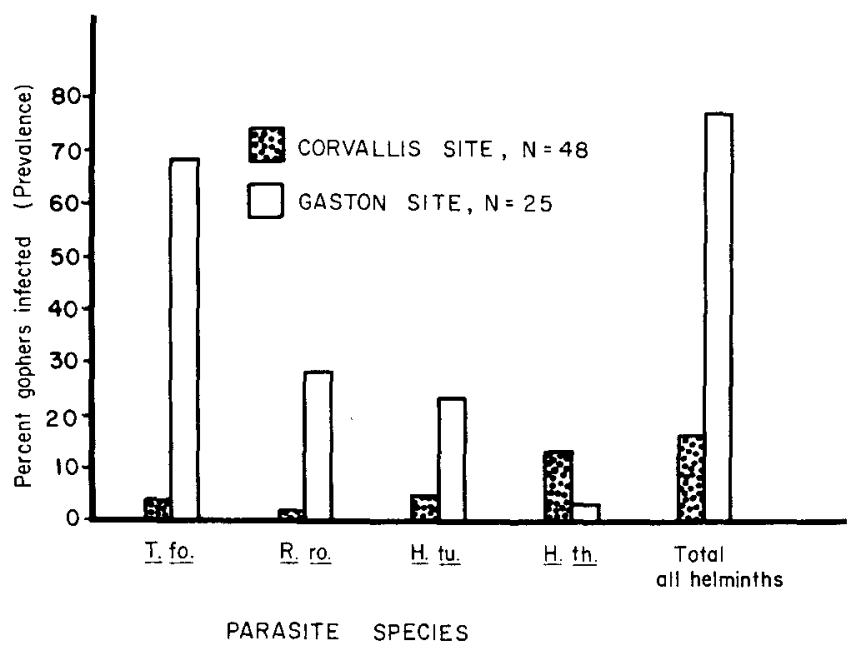

FIG. 1. Prevalence of infection of four species of helminths occurring in Thomomys bulbivorus from two areas of the Willamette Valley of Oregon. Hymenolepis horrida was found in only one host and is not represented here. T. fo., Trichuris fossor; $R$. ro., Ransomus rodentorum; H. tu., Hymenolepis tualatinensis; H. th., Heligmosomoides thomomyos.

the same method.

All experimental animals were handled in accordance with the standards established by the Canadian Council on Animal Care.

\section{Results}

Helminths collected from $T$. bulbivorus are considered below by species. Data concerning prevalence are summarized in Fig. 1.

\section{Nematoda}

Trichuris fossor Hall, 1916 occurred in the cecum of 19 $(26 \%)$ of the animals with a range of 1 to $36(\bar{x}=11)$. The ratio of males to females was $1: 1$. A difference $(p<0.05)$ in prevalence of infection between study sites in the Willamette Valley was observed (Fig. 1). Some seasonal fluctuation in prevalence was observed, with a statistically significant change from spring through summer from $15 \%$ to $55 \%$, respectively. This whipworm is a common and host-specific nematode in pocket gophers. It has been reported from pocket gophers of other species by Hall (1916), including Thomomys fossor Allen ( $=T$. talpoides (Richardson)) in Colorado; Chandler (1945) from $T$. bottae in California; Tryon (1947) from $T$. talpoides in Montana; Lubinsky (1957) from $T$. talpoides in Alberta; Frandsen and Grundmann (1961) from $T$. talpoides and $T$. umbrinus (Richardson) in Utah; Douglas (1969) from T. bottae in Colorado; and Todd et al. (1971) from T. talpoides in Wyoming.

Ransomus rodentorum Hall, 1916 was present in the cecum and large intestine of $8(11 \%)$ of the gophers examined, with a range of 1 to $5(\bar{x}=2)$. The ratio of males to females was 1:0.9. A statistically significant difference in prevalence of infection ( $p<0.05$ ) between study sites was noted (Fig. 1). This nematode, also host specific in geomyids, has been reported by Hall (1916) from $T$. talpoides (type host) in Colorado; Frandsen and Grundmann (1961) from both $T$. talpoides and T. umbrinus in Utah; Todd et al. (1971) from T. talpoides in Wyoming; and Jasmer (1980) from T. bottae in northern California.

Heligmosomoides thomomyos Gardner and Jasmer, 1983 was found in the duodenum of $7(10 \%)$ of the hosts, with a range of 1 to $5(\bar{x}=3)$. The ratio of males to females was $1: 2$. Nematodes of the genus Heligmosomoides are commonly found in the small intestine or cecum of rodents of the families Arvicolidae, Muridae, and Cricetidae (Durette-Desset 1971; Rausch and Rausch 1973). Heligmosomoides thomomyos has been recorded also from Thomomys bottae in California by Gardner and Jasmer (1983).

Specimens of these nematodes have been deposited in the United States National Museum Helminthological Collection, as follows: Trichuris fossor Hall, 1916, No. 78416; Ransomus rodentorum Hall, 1916, No. 78417; Heligmosomoides thomomyos Gardner and Jasmer, 1983, holotype, No. 76610.

\section{Cestoda}

Hymenolepis horrida (von Linstow, 1901) occurred in the small intenstine (duodenum) of $1(2 \%)$ of the gophers. The infection was light, with only 3 specimens present. This cestode has been reported from rodents of the families Arvicolidae, Cricetidae, Muridae, and Sciuridae, as well as from a geomyid ( $T$. bottae) in California (Schiller 1952; Voge 1952). It has also been reported from Thomomys monticola Allen in California (Howard and Childs 1959) and from $T$. talpoides and T. umbrinus in Utah (Frandsen and Grundmann 1961).

Hymenolepis tualatinensis $\mathrm{n} . \mathrm{sp}$. was found in the duodenum of $7(10 \%)$ of the gophers examined. A difference in prevalence of this cestode between study sites was significant at $p<0.05$. Numbers of this cestode in individual animals ranged from 1 to $38(\bar{x}=14)$.

The following description is based on 8 fully developed cestodes; 25 additional specimens were also studied, including one collected by $\mathrm{C}$. Maser from the same host near Adair, Oregon. All measurements are given below in micrometres unless otherwise stated. Means are given in parentheses.

\section{Hymenolepis tualatinensis $\mathrm{n} . \mathrm{sp}$.}

(Figs. 2-5)

DESCRIPTION: Strobila 24-210 mm (79) long, with 274 to 602 (457) segments; maximum width $1.75 \mathrm{~mm}$, attained in early gravid segments. Strobilar margins serrate, with intersegmental boundaries and velum well defined in mature segments. Segments wider than long; strobila attenuated anteriorly, with increase in relative length beginning in mature segments; mean length/width ratio of mature and gravid segments 0.28 and 0.53 , respectively. Scolex $92-167$ (120) wide slightly set off from neck. Rostellum unarmed, 6-17 (12) long; rostellar sac 51-61 long. Neck 305-1890 (1181) long, and 97-141 (120) wide. Genital pores unilateral, usually dextral; sometimes irregularly alternating in part or entire strobila. Genital ducts passing dorsally across ventral longitudinal excretory canals. Ventral canals 14-38 (21) in diameter, connected by narrow transverse ducts, sometimes branching at junction with ventral canals aporally. Dorsal canals $1-2$ wide, visible in scolex, then becoming indistinct in region of neck and usually not discernable in rest of strobila. Cirrus sac elongate, piriform, 56-150 (99) long by 26-49 (34) in maximum diameter; directed posteriad, with aporal end frequently overlapping ventral longitudinal excretory canal. Cirrus spinose. Internal seminal vesicle piriform in shape, 41-80 (57) in length by $14-40(27)$ in maximum diameter. Duct to cirrus sac making one loop medial to excretory canal, then dilating to form external seminal vesicle; sometimes with vas deferens distended for entire length. If discrete, external seminal vesicle 
elongate piriform, 28-134 (69) in length by $11-49$ (26) in maximum diameter, situated dorsally to vagina and anterior to poral testis. Testes subspherical, 63-141 (94) in transverse diameter by 54-141 (75); usually one poral and two aporal. Aporal testes situated lateral to, and not overlapping ovary; usually one anterior and one posterior in segment. One to four testes per segment not unusual. Seminal receptacle 48-169 (105) in transverse length by $23-70$ (39) in maximum diameter, extending porad anterior to ovary. Ovary weakly bilobed with many smaller lobules; 96-216 (136) in transverse diameter by $24-199$ (170) in length, situated medially in segment (Fig. 4). Vitelline gland with smooth margins or weakly lobed, 37-132 (74) wide by 34-109 (51) in length, situated ventrally at posterior margin of segment near midline in space immediately posterior to ovary; ovary sometimes overlapping vitelline gland anterio-dorsally. Uterus arising as sac dorsal to ovary, expanding first porally and then, as ova begin to enter, becoming lobate and expanding to fill segment dorsally without displacement of genital organs. Gravid uterus filling whole segment except space anterior to cirrus sac and seminal receptacle; overlapping ventral excretory canals dorsally. Genital ducts persisting in gravid segments; seminal receptacle prominent and enlarged. Eggs (Fig. 6) subspherical with thin outer covering, 57-89 (77) by 42-68 (61). Embryo (Fig. 6) 23-49 (38). Each member of middle pair of embryonic hooks identical in size and shape; 17-20 (19) long by $2.0-3.0$ wide at handle. First and third pairs of hooks 14-18 (16) long with individual dimorphism in width evident. Outer hook of each pair always thinner. The largest and smallest hooks of the first and third pairs 3-4 and 2 wide at handle, respectively.

TYPE HOST: Thomomys bulbivorus (Richardson)

HABITAT: Duodenum

TYPE LOCALITY: Washington County, Oregon $\left(123^{\circ} 8^{\prime} 51^{\prime \prime} \mathrm{N}\right.$, $45^{\circ} 25^{\prime} 34^{\prime \prime} \mathrm{W}$ )

HOLOTYPE: USNM Helm. Coll No. 78418, from pocket gopher collected on March 17, 1979

PARATYPES: 2 specimens from Thomomys bulbivorus collected on September 8, 1981 in Benton County, Oregon $\left(123^{\circ} 16^{\prime} 36^{\prime \prime} \mathrm{N}, 44^{\circ} 32^{\prime} 54^{\prime \prime} \mathrm{W}\right)$. USNM Helm. Coll. No. 78419

\section{Comparisons}

Cestodes of the genus Hymenolepis Weinland, 1858 (sensu stricto) occur widely in rodents in the Holarctic region. According to Yamaguti (1959), the genus Hymenolepis s. str. includes those species having the following characteristics: rostellum lacking or rudimentary; unarmed suckers; three testes, one poral and two aporal; typically occurring in rodents.

The family Geomyidae originated in the Nearctic region and there is no evidence that geomyids existed in the Palearctic (Kurtén and Anderson 1980; Simpson 1945). Presently, the geographic center of origin of the genus Hymenolepis s. str. is unknown. Recent work by Gardner (1983) has shown that members of the family Geomyidae have a diverse fauna of cestodes representing the genus Hymenolepis s. str. This diversity of hymenolepidids infecting gophers indicates that there has been a long evolutionary association between the host and members of this genus of parasite. Because of this it is probable that $H$. tualatinensis arose in situ in $T$. bulbivorus rather than representing a recent "captural phenomenon." It is obvious that no host interchange across the Bering Strait has occurred; therefore, $H$. tualatinensis must represent a distinct evolutionary entity separate from the species of Hymenolepis that occur in the Palearctic region. For this reason, I am re- stricting comparisons of species to those hymenolepidids known to occur in nearctic mammals.

In addition to the records of $H$. horrida, cited above, cestodes of the genus Hymenolepis have been reported from pocket gophers as follows. Cestodes representing several species of Hymenolepis were reported by Douthitt (1915) from Geomys spp. in the central United States, but none was identified. Rankin (1945) reported $H$. diminuta from Thomomys talpoides near Grand Coulee, Washington, and it was identified also from Geomys bursarius (Shaw) in Oklahoma by Burnham (1953). Voge (1955) listed $H$. citelli McLeod, 1933 and Hymenolepis sp. from $T$. bottae in California. Hymenolepis citelli was reported also from $T$. talpoides and T. umbrinus in Utah by Frandsen and Grundmann (1961).

Hymenolepis tualatinensis $\mathrm{n}$. $\mathrm{sp}$. was compared directly with $H$. diminuta (10 specimens reared experimentally, see below), $H$. citelli (5 specimens reared experimentally, see below), and $H$. horrida (3 specimens from $T$. bulbivorus; present study). In addition, comparisons were made with the type specimen (USNM Helm. Coll. No. 38261) and published description of $H$. pitymi Yarinsky, 1952, from the pine vole, Pitymys pinetorum (Le Conte) in Tennessee, the type specimen (USNM Helm. Coll. No. 9259) and published description of $H$. scalopi Schultz, 1939 from Scalopus aquaticus (Linnaeus) collected near Stillwater, Oklahoma (Schultz 1939), and the published description of Hymenolepis neürotrichi Rausch, 1962, from Neürotrichus gibbsii (Baird) collected from western Oregon (Rausch 1962). Hymenolepis diminuta and $H$. horrida are cosmopolitan and holarctic in distribution, respectively. The four remaining species, $H$. pitymi, $H$. scalopi, $H$. citelli, and $H$. neürotrich $i$ have thus far been reported only in mammals of the Nearctic region.

Hymenolepis tualatinensis $\mathrm{n}$. sp. is distinguished immediately from $H$. horrida by the characteristics of the egg, which is oval in shape, containing an embryo surrounded by a membrane lacking polar projections (Fig. 6). In $H$. horrida, the embryo is elongate, and the embryophore has polar projections (von Linstow 1901) (Fig. 7). The embryonic hooks in eggs of $H$. tualatinensis are larger and more robust than those of $H$. horrida and the two species are rather similar in other characteristics. Hymenolepis tualatinensis has a prominent rostellum, but this structure is absent in $H$. horrida, in which the suckers are quite protrusible, as compared with those of H. tualatinensis (see Table 1).

Fully developed specimens of $H$. citelli (obtained from Dr. A. W. Grundmann, University of Utah) from experimentally infected hamsters were compared directly with both $H$. dimin$u t a$ and $H$. tualatinensis. No differences in mensural or qualitative characters of the fully developed strobilae of $H$. diminuta and $H$. citelli could be demonstrated. Although Rausch and Tiner (1948) and Hansen (1950) concluded that these two species cannot be distinguished in the strobilar stage, Voge (1969) showed they could be differentiated using characteristics of the larval stages. No developmental stages of $H$. tualatinensis were studied; therefore, characters distinguishing $H$. tualatinensis from $H$. diminuta in the strobilar stage will also serve to distinguish it from $H$. citelli.

Hymenolepis tualatinensis $\mathrm{n}$. sp. differs from $H$. diminuta in having a strobila of much smaller size. Voge (1952) reported that the strobila of $H$. diminuta attains a length of as much as $600 \mathrm{~mm}$, with a maximum width of $4 \mathrm{~mm}$. The strobila of $H$. tualatinensis has markedly serrate margins, whereas the margins in $H$. diminuta are smooth. In $H$. tualatinensis, the testes 

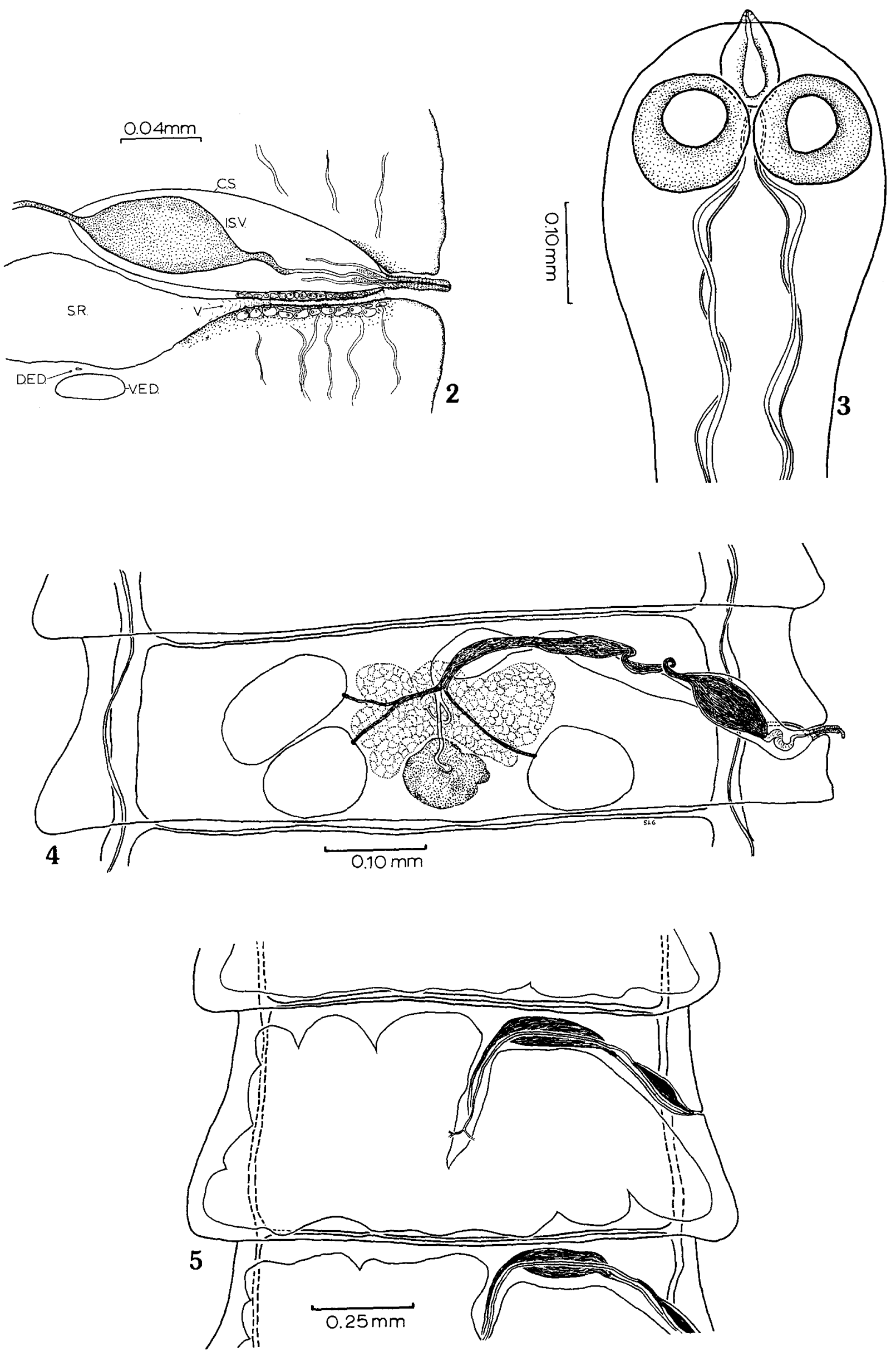

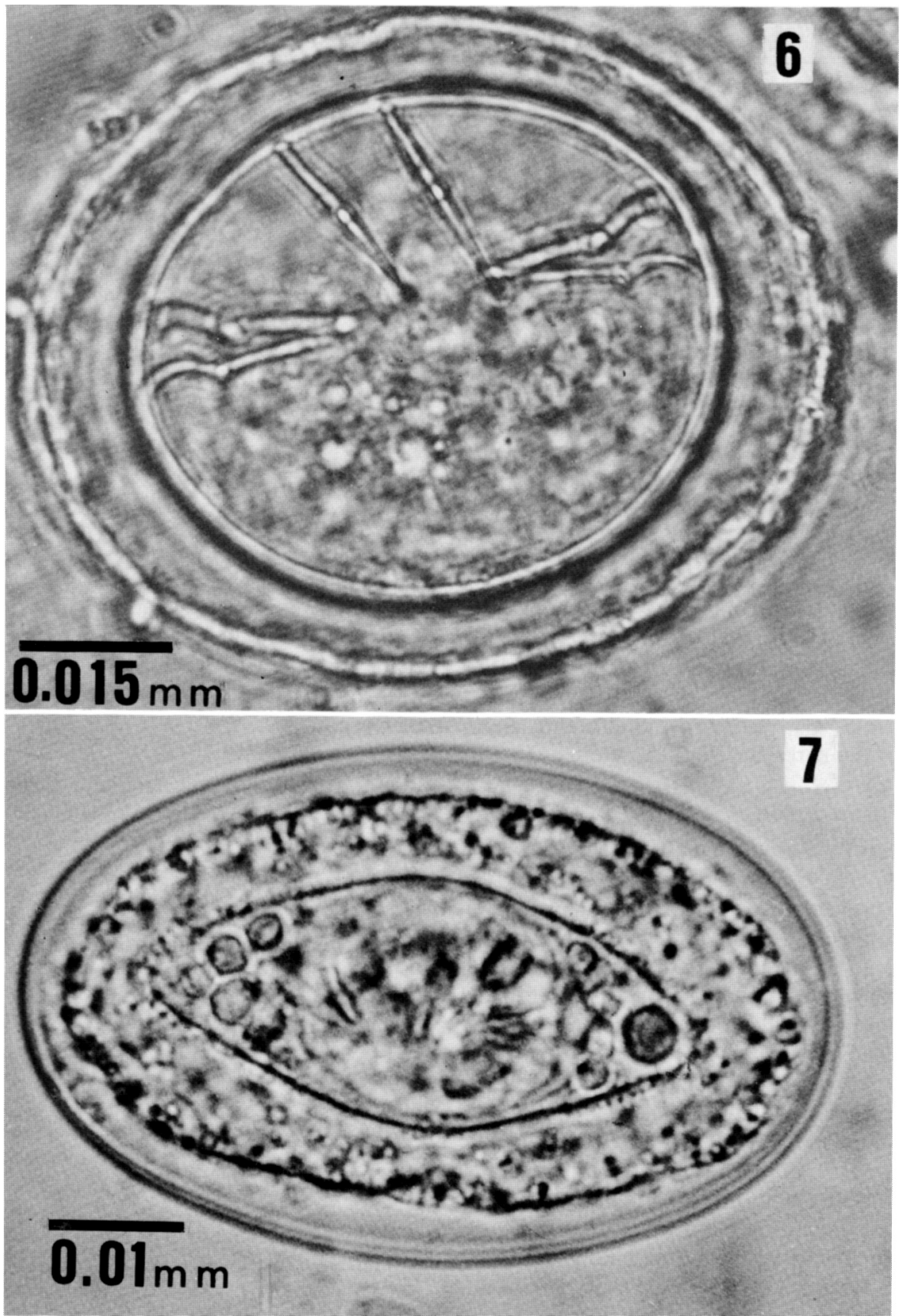

FIG. 6. Egg of Hymenolepis tualatinensis n. sp., embryo and well-developed embryonic hooks visible. FIG. 7. Egg of Hymenolepis horrida, spindle-shaped embryo and minute embryonic hooks visible.

are always arranged in a triangle (Fig. 4), whereas they are typically linear in $H$. diminuta. Specimens of $H$. tualatinensis differ from $H$. diminuta from experimentally infected rodents in having smaller length/width ratios of mature and gravid proglottids, a shorter cirrus sac, and a shorter internal seminal vesicle, which is piriform in shape rather than elongate and fusiform (Table 1).

Attempts to infect beetles with eggs of $H$. tualatinensis were unsuccessful; however, beetles of the same species became infected by $H$. diminuta (see Materials and methods).

From $H$. pitymi, $H$. tualatinensis differs in having a much larger strobila, a much smaller rostellum, a larger vitelline gland, a weakly bilobed ovary rather than an "almost divided" ovary as in $H$. pitymi, and a much larger egg (Table 1 ).

Hymenolepis tualatinensis $\mathrm{n}$. sp. can be separated from the two species of Hymenolepis described from nearctic insectivores by the following. Hymenolepis tualatinensis differs from $H$. scalopi by possessing a much smaller scolex, a smaller

FIG. 2. Cross section of segment of $H$. tualatinensis. CS, cirrus sac; ISV, internal seminal vesicle; SR, seminal receptacle; V, vagina; DED, dorsal excretory duct; VED, ventral excretory duct. FIG. 3. Scolex of $H$. tualatinensis. Fig. 4. Dorsal view of mature segment of $H$. tualatinensis. FIG. 5. Dorsal view of gravid segment of $H$. tualatinensis. 
TABLE 1. Range of measurements (in micrometres unless otherwise indicated) of five species of Hymenolepis s. str. from nearctic rodents and insectivores

\begin{tabular}{|c|c|c|c|c|c|c|}
\hline & H. tualatinensis & H. diminuta & H. pitymi & H. scalopi & $H$. neürotrichi & H. horrida \\
\hline Strobila length & $23.9-210 \mathrm{~mm}$ & $128-328 \mathrm{~mm}$ & $19.6 \mathrm{~mm}$ & $100-200 \mathrm{~mm}$ & $50 \mathrm{~mm}$ & $80 \mathrm{~mm}$ \\
\hline Maximum width & $385-1547$ & $1.44-2.94 \mathrm{~mm}$ & 750 & $3 \mathrm{~mm}$ & $2 \mathrm{~mm}$ & $2.14 \mathrm{~mm}$ \\
\hline No. of segments & $247-602$ & $1025-1188$ & 350 & $999-1070$ & - & - \\
\hline $\mathrm{L} / \mathrm{W}$, mature segments & $0.18-0.36$ & $0.9-0.12$ & 0.25 & - & 0.13 & 0.33 \\
\hline $\mathrm{L} / \mathrm{W}$, gravid segments & $0.43-0.69$ & $0.11-0.24$ & - & 0.07 & 0.50 & - \\
\hline Cirrus sac length & $56-150$ & $202-388$ & 79 & 125 & $90-110$ & - \\
\hline Internal seminal vesicle length & $41-80$ & $105-256$ & $51-70^{*}$ & - & - & 89 \\
\hline External seminal vesicle length & $28-134$ & $141-247$ & 77 & 一 & - & 35 \\
\hline Seminal receptacle length & $48-169$ & $71-540$ & $155-241$ & - & - & - \\
\hline Ovary width & $96-126$ & $108-133$ & $97-116^{*}$ & $125-220$ & - & - \\
\hline Vitelline gland width & $37-172$ & $47-99$ & 30 & $50-82$ & - & - \\
\hline Egg length & $57-89$ & $67-83$ & 28 & $57-65$ & $43-48$ & 68 \\
\hline Egg width & $42-68$ & $61-77$ & 31 & - & $15-18$ & 34 \\
\hline Embryo length & $23-49$ & $36-42$ & 23 & - & 27 & 15 \\
\hline Embryo width & $19-49$ & $31-36$ & 20 & $27-30$ & 14 & 10 \\
\hline
\end{tabular}

* Measurements made by me of Hymenolepis pitymi (type specimen) in May 1983.

strobila, fewer segments, and a much greater length/width ratio of the gravid segments (Table 1 ); $H$. tualatinensis differs from $H$. neürotrichi in that the former possesses a welldeveloped rostrum on the scolex and an egg of different form and size. These two species also differ in the structure and developmental pattern of the early stages of the uterus.

\section{Discussion}

Seasonal changes in prevalence of helminths in the populations of $T$. bulbivorus were evident only in the case of $T$. fossor. The increase in prevalence of $T$. fossor in the populations of $T$. bulbivorus from early spring through summer may be due to both biotic and abiotic factors that influence the infectivity of the larval nematodes, or perhaps the susceptibility of the gophers to become infected. One such factor, the increasing temperature of subsurface soil, is correlated with the attainment of infectivity by eggs or larvae of nematodes (Jasmer 1980). The increase in infective potential of these nematodes during the summer may be manifested by an increase in prevalence because of a greater probability that gophers would come in contact with infective eggs.

Immunogenic regulation may play the greatest role in limiting the numerical density of the helminth populations in individuals of $T$. bulbivorus. Wassom et al. (1973) showed that a single autosomal gene controls the immunity of Peromyscus maniculatus (Le Conte) to $H$. citelli. Initial numbers of colonizing cestodes are also important in the elicitation of an immune response in the Rattus norvegicus - Hymenolepis diminuta system (Hopkins 1980).

Differences in prevalence of infection between study sites (see Fig. 1) in the Willamette Valley may be an indication of differences in microhabitat available for both infective larvae and intermediate hosts. The primary factors affecting the distribution and prevalence of the cestodes are probably the density and distribution of the species of invertebrates that serve as intermediate hosts.

\section{Acknowledgments}

I thank Robert L. Rausch, Gerald D. Schmidt, Eric S. Loker, and Donald W. Duszynski for their helpful comments and technical advice. I was able to study the type specimen of $H$. pitymi through the assistance of J. Ralph Lichtenfels, cura- tor of the United States National Parasite Collection. Albert W. Grundmann kindly lent me specimens of $H$. citelli. I especially thank the late Mr. Loren Smith and his family who graciously allowed my trapping on their property in the Willamette Valley of Oregon.

BURNHAM, G. L. 1953. A study of the helminth parasites of the pocket gophers of Woods, Alfalfa, Grand, and Marshall Counties, Oklahoma. Proc. Okla. Acad. Sci. 34: 59-61.

CHANDLER, A. C. 1945. Trichuris species from California rodents. J. Parasitol. 31: 284-286.

DouGlAS, C. L. 1969. Ecology of pocket gophers of Mesa Verde, Colorado. In Contributions in mammalogy. Edited by J. K. Jones. Misc. Publ. Univ. Kans. Mus. Nat. Hist. 18: 147-175.

DouTHITT, H. 1915. Studies on the cestode family Anoplocephalidae. Univ. Ill. Bull. 1: $355-446$.

DURETTE-DESSET, M. C. 1971. Essai de classification des nématodes héligmosomes: Corrélations avec la paléobiogéographie des hôtes. Mém. Mus. Natl. Hist. Nat. Paris, Ser. A, Zool. 69: 1-126.

FRANDSEN, J. C., and A. W. GRUNDMANN. 1961. Endoparasitism in isolated populations of rodents of the Lake Bonneville basin, Utah. J. Parasitol. 47: 391-396.

GARDNER, S. L. 1983. Endoparasites of North American pocket gophers. M.Sc. thesis, University of Northern Colorado, Greeley.

GARDNER, S. L., and D. P. JASMER. 1983. Heligmosomoides thomomyos n. sp. (Nematoda: Heligmosomidae) from pocket gophers, Thomomys spp. (Rodentia: Geomyidae) in Oregon and California. Proc. Helminthol. Soc. Wash. 50: 278-284.

HALL, E. R., and K. R. KELSON. 1959. The mammals of North America. Ronald Press Co., New York. pp. 411-472.

HALL, M. C. 1916. Nematode parasites of the orders Rodentia, Lagomorpha, and Hyracoidea. Proc. U.S. Natl. Mus. 50: 1-285.

HANSEN, M. F. 1950. A new dilepidid tapeworm and notes on other tapeworms of rodents. Am. Midl. Nat. 43: 478-479.

HEYNEMAN, D. 1958. Effect of temperature on rate of development and viability of the cestode Hymenolepis nana in its intermediate host. Exp. Parasitol. 7: 372-382.

Hopkins, C. A. 1980. Immunity to Hymenolepis diminuta. In Biology of the tapeworm Hymenolepis diminuta. Edited by H. P. Arai. Academic Press, New York. pp. 551-614.

HowARD, W. E., and H. E. CHILDS. 1959. Ecology of pocket gophers with emphasis on Thomomys bottae mewa. Hilgardia, 29: $277-358$.

JASMER, D. P. 1980. The parasites of the Botta pocket gopher, Thomomys bottae and the taxonomy and biology of Ransomus rodentorum. M.Sc. thesis, Humboldt State University, Arcata, CA. 
KuRTÉn, B., and E. ANDERSON. 1980. Pleistocene mammals of North America. Columbia University Press, New York. pp. 223-229.

LUBINSKY, G. 1957. List of helminths from Alberta rodents. Can. J. Zool. 35: 623-627.

RANKIN, J. S. 1954. Ecology of the helminth parasites of small mammals collected from Northrup Canyon, Upper Grand Coulee, Washington. Murrelet, 26: 11-14.

RAUSCH, R. L. 1962. Helminths of the shrew-mole Neürotrichus gibbsii (Baird) in Oregon. J. Parasitol. 48: 813-817.

RAUSCH, R. L., and V. R. RAUSCH. 1973. Heligmosomoides johnsoni sp. nov. (Nematoda: Heligmosomatidae) from the heather vole, Phenacomys intermedius Merriam. Can. J. Zool. 51: 1243-1247.

RausCH, R. L., and J. D. Tiner. 1948. Studies on the parasitic helminths of the north central states. I. Helminths of Sciuridae. Am. Midl. Nat. 39: 728-747.

RoBERTS, L. S. 1980. Development of Hymenolepis diminuta in its definitive host. In Biology of the tapeworm Hymenolepis diminuta. Edited by H. P. Arai. Academic Press, New York. pp. 357-423.

Russell, R. J. 1968. Evolution and classification of pocket gophers of the subfamily geomyinae. Univ. Kans. Publ. Mus. Nat. Hist. 16: $473-579$.

SCHILLER, E. L. 1952. Studies on the helminth fauna of Alaska X. Morphological variation in Hymenolepis horrida (von Linstow, 1901) (Cestoda: Hymenolepididae). J. Parasitol. 38: 554-586.

SCHULTZ, R. L. 1939. Hymenolepis scalopi n. sp. Am. Midl. Nat. 21: 641-645.

SIMPSON, G. G. 1945. The principles of classification and a classi- fication of mammals. Bull. Am. Mus. Nat. Hist. 85: 1-350.

SOKAL, R. R., and F. J. RoHLF. 1969. Biometry. W. H. Freeman and Company, New York.

TODD, K. S., D. L. LEPP, and C. A. TRYON. 1971. Endoparasites of the northern pocket gopher from Wyoming. J. Wildl. Dis. 7: $100-104$.

TRYON, C. A. 1947. The biology of the pocket gopher (T. talpoides) in Montana. Mont. State Agric. Exp. Stn. Bull. No. 448. pp. $2-30$.

VOGE, M. 1952. Variation in some unarmed Hymenolepididae (Cestoda) from rodents. Univ. Calif. Publ. Zool. 57: 1-52.

1955. A list of cestode parasites from California mammals. Am. Midl. Nat. 54: 413-417.

1969. Systematics of cestodes: present and future. In Problems in systematics of parasites. Edited by G. D. Schmidt. University Park Press, Baltimore. pp. 49-79.

vON LiNSTOW, O. 1901. Taenia horrida, Tetrabothrium macrocephalum and Heterakis distans. Arch. Naturgesch. 1: 1-10.

Wassom, D. L., V. M. Guss, and A. W. GRUNDMANN. 1973. Host resistance in a natural host - parasite system. Resistance of Hymenolepis citelli by Peromyscus maniculatus. J. Parasitol. 59: $117-121$.

YAMAGUTI, S. 1959. Systema Helminthium. Vol. II. The cestodes of vertebrates. Interscience Publishers, New York. pp. 415-420.

YARINSKY, A. 1952. Hymenolepis pitymi n. sp., a hymenolepidid cestode from the pine mouse. J. Tenn. Acad. Sci. 27: 150-152. 